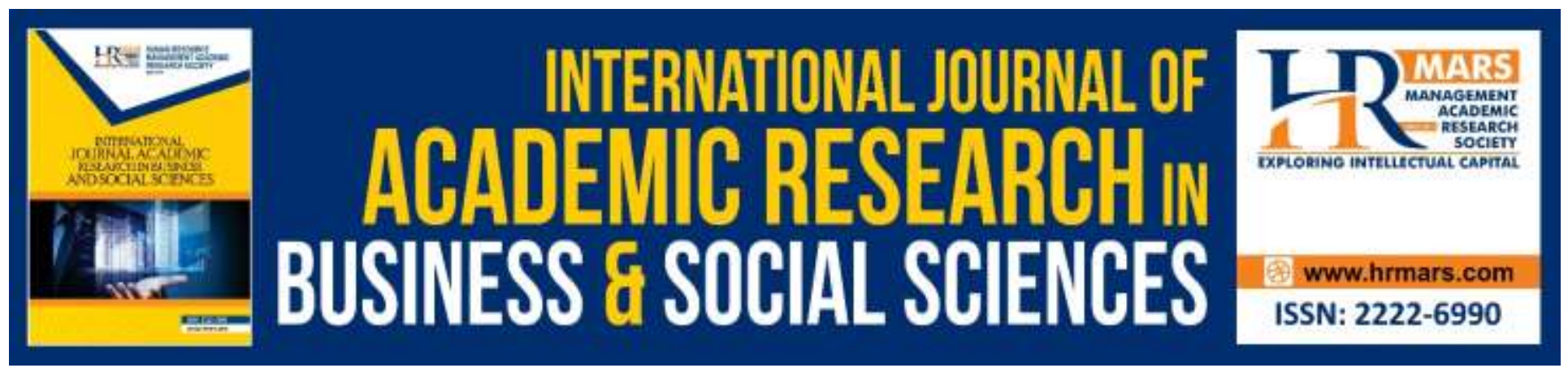

\title{
Letter Of Sultan Mahmud Riayat Syah To Governor-General Batavia Sir Willem Arnold Alting The Library Of Leiden University Collections: Does It Have Diplomatic Features?
}

Salmah Jan Noor Muhammad, Aone van Engelenhoven, Nadiatul Shakinah Abdul Rahman

To Link this Article: http://dx.doi.org/10.6007/IJARBSS/v10-i3/7027

DOI:10.6007/IJARBSS/v10-i3/7027

Received: 21 January 2020, Revised: 03 February 2020, Accepted: 20 February 2020

Published Online: 24 March 2020

In-Text Citation: (Muhammad et al., 2020)

To Cite this Article: Muhammad, S. J. N., Engelenhoven, A. van, \& Rahman, N. S. A. (2020). Letter Of Sultan Mahmud Riayat Syah To Governor-General Batavia Sir Willem Arnold Alting The Library Of Leiden University Collections: Does It Have Diplomatic Features? International Journal of Academic Research in Business and Social Sciences, 10(3), 102-112.

\section{Copyright: (C) 2020 The Author(s)}

Published by Human Resource Management Academic Research Society (www.hrmars.com)

This article is published under the Creative Commons Attribution (CC BY 4.0) license. Anyone may reproduce, distribute, translate and create derivative works of this article (for both commercial and non-commercial purposes), subject to full attribution to the original publication and authors. The full terms of this license may be seen at: http://creativecommons.org/licences/by/4.0/legalcode

Vol. 10, No. 3, 2020, Pg. $102-112$

Full Terms \& Conditions of access and use can be found at http://hrmars.com/index.php/pages/detail/publication-ethics 


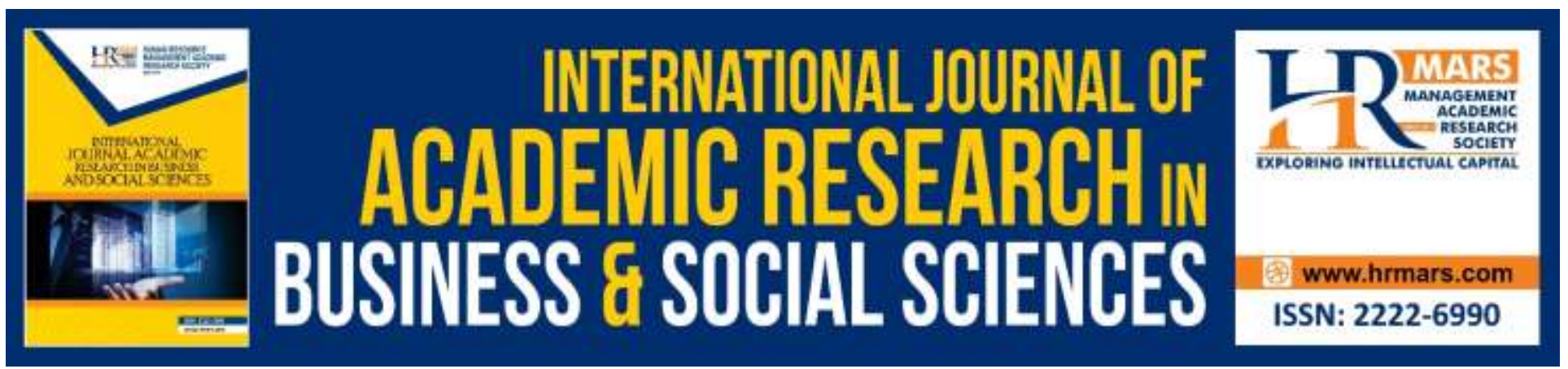

\title{
Letter Of Sultan Mahmud Riayat Syah To Governor- General Batavia Sir Willem Arnold Alting The Library Of Leiden University Collections: Does It Have Diplomatic Features?
}

\author{
Salmah Jan Noor Muhammad \\ Department of Malay Language, Faculty of Modern Languages and Communication, Universiti Putra \\ Malaysia, Malaysia
}

Aone van Engelenhoven

Institute for Area Studies, Leiden University, Netherlands

Nadiatul Shakinah Abdul Rahman

Department of Malay Language, Faculty of Modern Languages and Communication, Universiti Putra Malaysia, Malaysia

\begin{abstract}
Letter from Sultan Mahmud of Riah Syah from the State of Johore and Pahang addressed to Governor-General Willem Arnold Alting dated on 12 Ramadhan 1211 or March 11, 1797. It is a letter written in handwritten Jawi, beautifully illustrated and preserved in the Leiden University Library. In this sense, the question that might be raised is does this beautiful letter has diplomatic features in it? Therefore, the objective of this study is to identify and analyze diplomatic content through this delivery portal. The library methodology and diplomacy of Islamic theory will be applied in this study. Expectations of the findings show that indeed these poles have diplomatic features that can strengthen relations between governments. Hence, it is expected that the results of this study may help researchers to identify and study the letters of various aspects of the Malay sultanate.

Keywords: Letter, Sultan Mahmud of Riah Syah, Governor-General Willem Arnold Alting, Diplomatic, Leiden University, Johore, Batavia
\end{abstract}

\section{Introduction}

The letters of the Sultan Mahmud Riayat Syah from the states of Johor and Pahang were addressed to Governor-general Willem Arnold Alting dated on 12 Ramadan 1211 or 11 March 1797 which was a letter belonging to the category of decorated letters. This letter was received in Batavia on $28 \mathrm{March}$ 
INTERNATIONAL JOURNAL OF ACADEMIC RESEARCH IN BUSINESS AND SOCIAL SCIENCES Vol. 10, No. 3, March, 2020, E-ISSN: 2222-6990 @ 2020 HRMARS

1797. The paper was filled with full illumination with the background of a beautiful gold-colored tree. There is a text divider and there is a clear decoration on each side of the text.

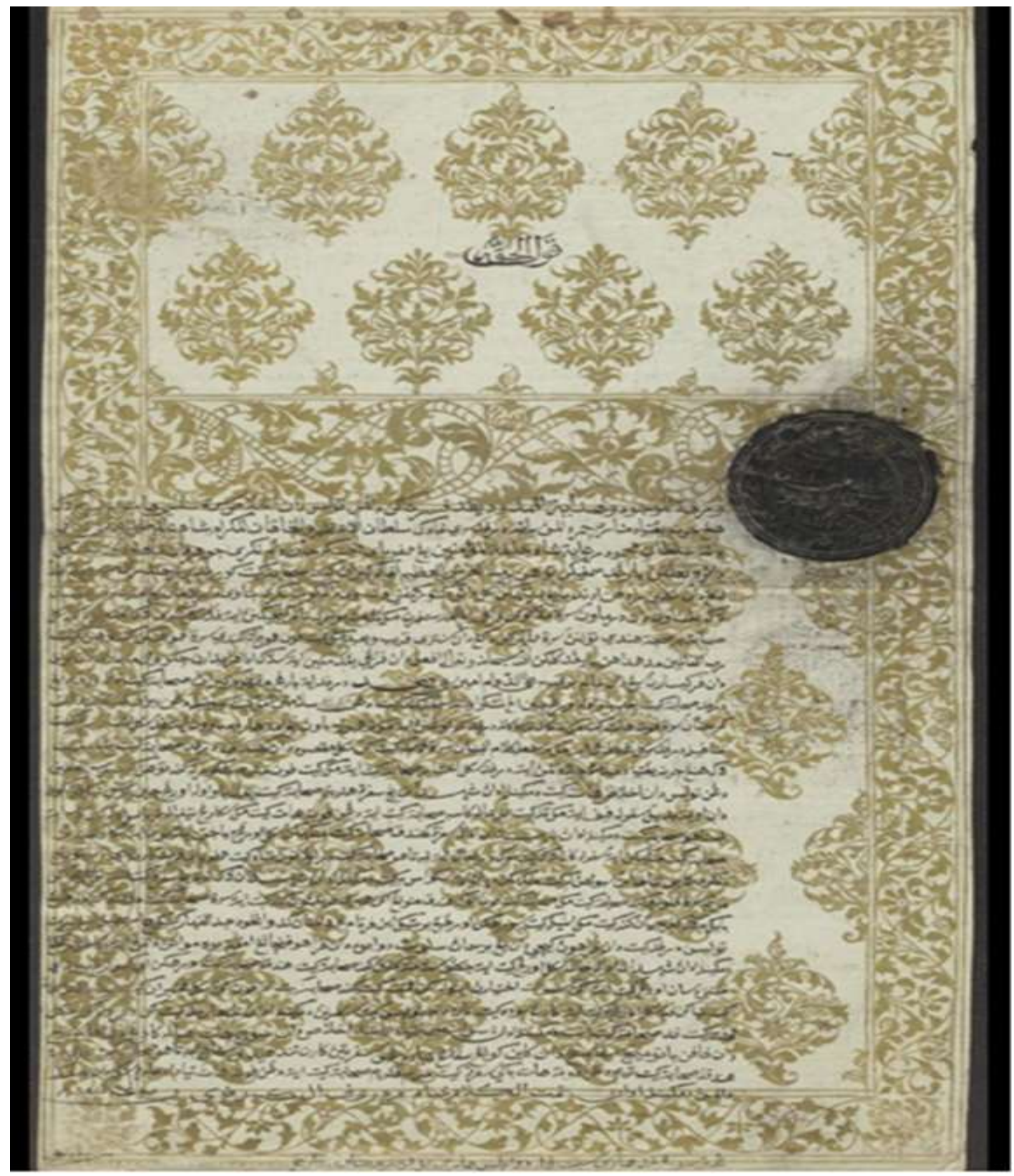

Figure 1: Leiden University Library Digital Collection: F008a

This letter is $52 \times 30 \mathrm{~cm}$, numbered or. 2241 I (8) Leiden University Library collection, the Netherlands. Have 29 lines in total used between 20 and 23 words per line. The writing is simple, neat and well-read. There is no engraving on the writing or calligraphy. It is completely black in black and there is a thick ink on the wa ba'du. There is the use of Arabic languages such as Waraqat al-wujud hidayat al-mamdûd, ziill al-Lāh fĩ al-ālam and khalīfat al-mu'minīn. Also on the right is a sheet of black seal and two circular circles on the inside of the circle bearing the name of Sultan Mahmud Riayat Syah ziill Allāh fĩ al-ālam ibn Sultan Abdul Jalil al-marhum bless Allāh 'alayhi. 


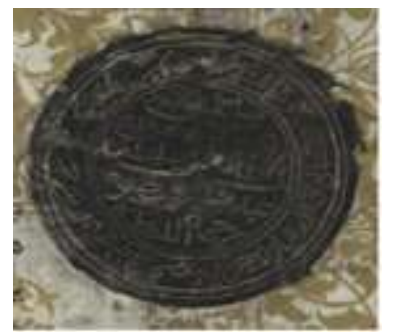

Figure 2: The seal used in Letters from Sultan Mahmud Riayat Syah from the state of Johor and Pahang was addressed to Governor-General Willem Arnold Alting dated 12 Ramadan 1211 or March 11, 1797.

\section{Literature Review}

Abd Razak Abd Karim (2015) says that Malay letters have very high internal arts. The art reflects the culture of the people who produce something. Muhammad (2017) says that the court clerk played an important role in the delivery of the wards. The results show that the close relationship between the writer and the king is one of the compelling factors for this group to translate the meaning of their king. These interrelated relationships can produce a richly illustrated essay that has a particularly positive impact on government diplomatic relations. The implication is that intellectual cooperation and compatibility through the two-party emotional approach will incorporate a high standard of the streak. Besides, Idris, Fadzal, Melebek (2017) also studied the old Malay letters around the 19th century from the point of absolute faith Malay. They use a sampling method, category, accounting system, records unit, and the unit in the context of identifying the absolute heart of the Malay contained in the letter. Results showed that there are as many as 8 sincerity Malay loyal to the head of a just, noble, and true, delicate courtesy and manners, respect and service in the association and front, plant cultivation and return the favor, the nature of love, honesty and sincerity, be kind to your fellow beings and trust. According to them, the sincerity of 8 items has raised the glory of the Malays in the eyes of outsiders.

Ab. Razak Ab. Karim \& Reniwati (2017) also focused their study on Malay letter illumination around the year 1521-1899. They say that there are elements of the lighting and the use of calligraphy in the Malay Mail that use color images of leaves and flora as a motif. Examples of cloves, Frangipani, water lilies, and, jasmine. Besides, geometric patterns are also very popular to use as illumination in a work. Ab Razak and Reniwati say that this illumination is the ability of creativity shown by the Malays and it also proves that the Malays are very skilled in sculpture and decorative arts. Gallop, (2018) article focuses on the stamp of the seal. According to him, the royal seal was mostly owned by the sultan and the king as the most important source for a ruler's name besides containing important information that was not presented in the letter sent. It turns out that the diversity of this study provides a source of information to the public. Haliah and Ab. Razak, Ab. Karim (2019) discusses the various aspects of cohesion as an element of social discourse in French letters. According to their social Malay letter built with the structure that differentiates it from other texts. Each component of the underlying text has a process related to each other as well as to the content. Therefore, the coherence of meaning and relationship between the elements of language in discourse can be traced by the role of cohesion. Meanwhile, Amin \& Endut (2019) also study the aesthetic value of the letters of the Malay rulers. Among the elements of concern are letterheads, stamps, words of praise, content, pre-closing, and closing. In the Malay civilization, a king is on a very high and noble. Thus, 
letters by the Malay rulers indeed have aesthetic value in which this matter is in line with the position of the 'human' is special.

However, according to Kamaruddin (2015) study of the Malay letters are still ignored, and this will cause the Malay will regret in the future if the research of the old Malay manuscript is not emphasized. Ab. Ab Karim Razak, which was a prolific researcher in the study of the Malay letter also often stressed in his writings that the study of letters, Malays letter are still lacking amongst scholars, although a lot of things that can be put forward for public consumption such as culture, art, and domains of many other aspects envisaged in the Malay letter. Revisiting the past researches, scholars are more focused on the physical aspects of a letter such as the illumination, design and seal of the sultan's. Hence, a diplomatic study necessary to de done to break out of the previous study. Beside that, from the urgency made by those scholars, this paper will focus on the Letter Of Sultan Mahmud Riayat Syah To Governor-General Batavia Sir Willem Arnold Alting as a main discourse with identifying and analyze diplomatic content through this delivery portal.

\section{Research Methodology}

This study uses the library method to obtain research data and apply the theory of Islamic diplomacy by Ahmed Musa. According to Musa (2009), there was a written procedure through a letter or letter that was applied by the Prophet s.a.w and his companions while sending letters to the surrounding government. Among them, the diplomatic letter begins with the name of Allah, declaring the name of the sender and his post, using the respectful call to the recipient, greeting, conveying the Islamic message using Quranic verses such as: "There is no God but Allah and the Prophet Muhammad s.a.w. It is the messenger of God," contains a clear and complete message and stamps the letter with a special stamp. In the meantime, there are four planned stages, namely, selecting, collecting, analyzing and summarizing data. At the stage of selecting the data, what is emphasized is the selection of the Malay sultanate letters. This stage is an important step in gaining an overall idea of the discussion. Further, at the data collection stage, research will be conducted on the findings that are in line with the identified research objectives. Each reading of the contents of the epistle will be researched and recorded, particularly information that covered the topic of the study. Meanwhile, at the data analysis level, the focus is on information obtained from the second stage and used as the main material in discussing the findings of the study. As a result of the analysis of the data, a summary of the findings will be made to describe the topic of the study.

\section{Findings}

\section{Diplomacy Practice In a letter}

Diplomacy is the art and practice of conducting negotiations between representatives of groups or governments. The term diplomacy is often referred to in the practice of international diplomacy. According to Frankel (1987), diplomacy is commonly used in the broad sense that includes aspects of policy formulation and implementation. In a more technical sense, it is meant to be a link between government and government. Meanwhile, Choudhury (1993) viewer's diplomacy as:

The aims of the Prophet's diplomacy, or his principle of international relations, was based on the concept of a just and fair world order, in which all states, strong or weak, big or small, should enjoy peace, stability, freedom of conscience and human welfare. 
In the conduct of foreign relations, the Prophet was always guided by the noble moral principles laid down in the Quran.

Diplomatic relations, which are an important agenda in international relations, give the nation or government an open choice, identifying the forms of relations (political, economic, social and cultural) that they wish to establish with others. This phenomenon can help a government avoid making wrong in decision making, establishing diplomatic relations with other governments. This is because the relationship is the starting point for developing relationships across national borders. The successes achieved by the methods of diplomacy in a Malay kingdom have inspired Sultan Mahmud Riayat Syah to develop strategies that are effective in delivering diplomacy celebrations, especially in the aspect of his business. Among the diplomacy practices used by Sultan Mahmud Riayat Syah through this process are:

1) Recognition of Recipient's Self

2) Words of Praise

3) Satisfaction in making requests

4) The prayer approaches

5) Gift Giving

\section{Recognition of Recipient's Self}

According to Koentjoro (1989), self-introduction is a step that is needed by someone to function effectively. However, in this context, self-identification is the first step taken by a government to inform the government as well as the government-administered to the recipients to facilitate the affairs of both parties. This is important, as this 'first encounter in writing' can provide a reflection or an overview of the overall background and intent of the sender to the recipient. The following is a statement of introduction by Sultan Mahmud Riayat Syah in the letter:

Waraqat al-wujud hidayat al-mamdûd yang dipesertakan dalamnya tulus dan ikhlas serta selesai hati yang suci lagi hening jernih yang tiada menaruh cemar dalamnya, yaitu daripada Paduka Sultan al-'aẓam wa al-khāqān al-mukarram Syah Alam z̦ill alLāh fì al-ālam, yaitu Sultan Mahmud Riayat Syah khalīfat al-mu'minīn yang mempunyai takhta kerajaan negeri Johor dan Pahang dan segala daerah taklukannya, ...

The introduction of Sultan Mahmud Riayat Syah's self-introduction was a strategy of open communication in the practice of diplomacy. Interestingly, in regards, Malay letter identity is still done in the first paragraph, even though the recipient to identify the sender of the letter. The words used are of personal value and interpret in an aesthetically pleasing language before delivering the actual message to the recipient. Usually, the court clerk is the person responsible for writing awards. Thus, this introductory greeting will form a beautiful sentence and can leave an impression on the recipient. This will create an atmosphere of warmth, comfort, intimacy, and goodwill between the two sides.

Add on to that, these introductory greetings also showcases the special glory of Sultan Mahmud Riayat Syah's personality in building and maintaining dignity while interacting with others in the writing world. This situation proves the hospitality and good image shown by a state government. 
INTERNATIONAL JOURNAL OF ACADEMIC RESEARCH IN BUSINESS AND SOCIAL SCIENCES

Vol. 10, No. 3, March, 2020, E-ISSN: 2222-6990 @ 2020 HRMARS

\section{Words of Praise}

Words of praise are often used by the French government as a preamble at the beginning of the speech after the greetings of identification. According to Gallop (1994), words of praise are a reflection of the efficiency of the Malay art of correspondence, which implies greatness and excellence civilization Malay royal palace, where the origin of this letter. It also shows that Malay culture is very familiar with the procedure of writing letters. The purpose of using these words of praise is to elevate the dignity of the recipient as a successful, influential or orally good government. According to Aziz (2006), the words of praise are highly motivating to an individual. Below are examples of the words of praise used in this letter.

barang disampaikan Tuhan rabb al-'arasy al-'aẓim apalah kiranya kepada sahabat kita Gurnadur Jenderal Meneer Willem Arnold Alting dan sekalian Raad India yang memerintahkan segala daerah kantor Kompeni Welanda dalam kota negeri Betawi Dār al-amān yang amat arif bijaksana lagi bangsawan dan dermawan serta melakukan perangai yang amat sempurna, maka telah mahsyurlah nama kebajikannya itu pada segala negeri lagi amat menolong kepada segala sahabatbersahabat handai taulannya serta memeliharakan dagang dan santri qarīb wa baîd. Maka kita pun memuji-muji akan dia serta memohonkan kepada Tuhan kita rabb al'alamin mudah-mudahan barang dikekalkan Allah subhānahu wa ta ālā af'āl dan perangai yang demikian itu selagi ada peredaran cakrawala matahari dan bulan dan perkisaran siang dan malam bertambah-tambah 'alā al-dawām. Amīn.

In the example above, the words of praise used by Sultan Mahmud Riayat Syah are interesting because besides praising Governor-General Willem Arnold Alting's personality 'yang amat arif bijaksana lagi bangsawan dan dermawan serta melakukan perangai yang amat sempurna,'. He also emphasized the good morals shown by the recipients, words like these 'maka telah mahsyurlah nama kebajikannya itu pada segala negeri lagi amat menolong kepada segala sahabat-bersahabat handai taulannya serta memeliharakan dagang dan santri qarīb wa ba'îd.'

The words of praise used above are evident in his constructive and sincere nature by Sultan Mahmud Riayat Syah in his quest to convey the inner essence of the message he sent. The recipient should not only feel appreciated, but his ability in administration is acknowledged as well. Besides, words of praise which he also used not only to recognize the Governor-General Willem, but in fact, there are aspects behind it, namely respect, manners, and Malay identity when dealing with others. According to Abdullah (2009) is indeed the Malays are known for their collectivistic which stressed the need to maintain harmonious relationships within the social environment.

\section{Satisfaction In Making Requests}

One of the things that can be seen in this section is Sultan Mahmud Syah's willingness to request Gurnadur General Willem Arnold Alting. His language delivery was clear, yet full of caution. The caution here is not due to suspicion or suspicion, but the caution here is to avoid misunderstanding the sender that the request expressed is in the form of instructions. Therefore, the request of the king was seen as unreasonable and forced. This is due to the sophistication of the language by 
INTERNATIONAL JOURNAL OF ACADEMIC RESEARCH IN BUSINESS AND SOCIAL SCIENCES

Vol. 10, No. 3, March, 2020, E-ISSN: 2222-6990 @ 2020 HRMARS

expressing the content correctly and organically and delivering meaning without confusing the sender. The following are examples of spoken language in making a request:

a) Request 1 is a request for help solving the plow people. The most famous pirates in Sulawesi are mainly from Sulu, the Ilanun, Balangingi and Mindanao people.

Syahdan adalah seperti kehendak sahabat kita menegahkan segala orang-orang bajak Ilanun itu, sekali kehendak sahabat kita menegahkan itu sepuluh kali lagi kita suka, dari hal itu lebih tahu sahabat kita dari llanun, tiada kita mempunyai perintah karena dia ada satu raja di negeri lain, tetapi ini seboleh-bolehnya kita menegahkan dianya itu sekuasa-kuasa kita, demikianlah adanya.

b) Request 2 is about helping get the cannon and ammunition. This situation has to do with strengthening the government's defense systems. According to Omardin Ashaari (2008) with strong defenses can determine the existence of peace in a country. As a result, the government will be able to develop and grow rapidly.

Syahdan lagi adalah yang seperti kita minta tolong bicarakan meriam serta peluru kepada sahabat kita, maka sahabat kita pun suka hendak menolong akan memberi perbantuan kepada kita itu, serta sahabat kita menghendak orang yang baik-baik lagi kepercayaan kepada kita. Maka inilah kita suruhkan orang yang bertiga ini, pertama Abdul Manan, kedua Takhwid Abdul Kahar, ketiga Haji Ismail. Inilah serta tulisan daripada kita dan perahunya kici dan bersamanya selub dua buah dan perahu pencalang empat buah muatnya dalamnya itu dagangan wangkang, demikianlah adanya.

The language spoken above is a characteristic of the personality of Sultan Mahmud Riayat Syah. A government with a strong character but rich in manners. According to Hashim Musa (2008), such behavior reflects humility, not arrogance, and arrogance, truth, compassion, sanctity, love of peace, high regard, mutual respect, cooperation, gratitude or gratitude, courtesy, and passionate community. In other words, it can help build relationships and harmony.

Besides that, the politeness of this letter is also closely related to Malay culture itself. According to Yule (1985), on the aesthetic value of the Malay culture indirectly has formed poetic language while politely. The use of language that is sweet and polite and has an intellectual significance will gain a great deal of attention and recognition from others, especially on the receiving end. The recipient will be able to assess the sender's personality roughly through the language used by the sender. It is synonymous with the expression 'language denotes a nation' which means good language denotes a good nation (Arshad, 2001). The good and courteous language that the sender promotes will increase the confidence in the recipient to continue dealing with the sender. Usually, the recipient will only have a relationship with the person who is willing to interact and facilitate all matters.

\section{The Prayer Approaches}

The prayer approaches are also one of the fillings contained in this book. This method is used to pray for the recipient to live in peace and among the approaches in Islam used to soften one's heart. This 
INTERNATIONAL JOURNAL OF ACADEMIC RESEARCH IN BUSINESS AND SOCIAL SCIENCES

Vol. 10, No. 3, March, 2020, E-ISSN: 2222-6990 @ 2020 HRMARS

method of prayer can be identified at the beginning of the chapter, and the expression of the prayer is usually followed by the phrase 'amen'. However, there is also the application of this method at the end of the paragraph. Some examples of the use of this prayer method can be seen in the following examples:

...serta memohonkan kepada Tuhan kita rabb al-'alamin mudah-mudahan barang dikekalkan Allah subhāanahu wa ta ālā af'āl dan perangai yang demikian itu selagi ada peredaran cakrawala matahari dan bulan dan perkisaran siang dan malam bertambah-tambah 'alā al-dawām. Amīn.

The nature of praying for others is one of the virtues contained within the Malay sultan. It reflects who they are. The recipient will also feel that the prayer requested by the sender is intended to seek safety and well-being. As a result, the spirit between the sender and the receiver becomes closer. According to Osb (1985), praying for others is very helpful for one to know himself and to know others.

\section{Gift Giving}

Gallop (1994), says that typically, after the conclusion of the main points in a letter, most of the Malay royal letters will specify gifts sent with the letter. This indicates that a piece of paper is considered complete when it is accompanied by a gift. Each visit or event you send will surely be accompanied by a variety of prizes. The gift has an implied meaning. Some governments give gifts based on political, economic and social interests (Muhammad, 2014).

In a letter sent by Sultan Mahmud Riayat Syah, it was stated that he had received a letter and also a gift of gifts from Gurnadur General Meneer Willem Arnold Alting. His happy feelings are also expressed in this book.

Examples of passage 1: expressing his feelings when he received the invitation.

Wa ba 'du daripada itu, barang mafhum kiranya sahabat kita adalah warkat yang daripada sahabat kita yang dibawa oleh orang Cina Ang Sye Kwa itu telah sampailah kepada kita dengan selamatnya, maka kita sambutlah dengan beberapa kesukaan dan keridaan serta putih hati kita. Maka tatkala terbukalah daripada gulungannya itu maka terhamburlah baunya itu pada segala insan serta kita tatapilah daripada segala syatarnya itu,...

Example of quote 2: Gift received by Sultan Mahmud Riayat Syah.

Syahdan yang seperti hadiah sahabat kita yang dibawa oleh orang Cina beras tiga puluh guni dan ubat bedil sepuluh pipa itu, maka telah kita terimalah kasih sahabat kita itu dengan putih hati kita. Maka sekarang tiadalah terbalas oleh kita kasih itu lebih tahu sahabat kita, demikianlah adanya. follows:

In return, Sultan Mahmud Riayat Syah also gifted General Gurnadur Willem Arnold Alting as 
INTERNATIONAL JOURNAL OF ACADEMIC RESEARCH IN BUSINESS AND SOCIAL SCIENCES Vol. 10, No. 3, March, 2020, E-ISSN: 2222-6990 @ 2020 HRMARS

Suatu pun tiada ada tanda ikhlas dan suci hati hanyalah gadang dua pasang dan papan batu meja sepasang dan kain gulung sepasang, tiada dengan sepertinya karena tanda hidup sahaja lebih tahu sahabat kita. Dari itu hendaklah sahabat kita terima dengan putih hati bagai seperti kita menerima pekirim sahabat kita itu dengan putih hati tiada menaruh syak dan sangka dalamnya, demikianlah adanya.

Gifts from both sides are a comprehensive way of maintaining their relationship. Some of the matching gifts of the couple were seen through the gift of rice from the Dutch and were rewarded with a handkerchief by Sultan Mahmud Riayat Syah. It can be seen that both sides need each other. That's what it looks like based on an analogy of rice without its packaging.

\section{Conclusions}

Letters are a legacy of legends that serve as a bridge to the tradition of writing between the government and other governments. There are various types of wards available overseas, such as the Leiden University Library, The Netherlands. This Jawi script needs to be interpreted and analyzed in order to know its contents and to recognize its external physical content. For example, the Sultan Mahmud Riayat Syah from Johor and Pahang presented to General Willem Arnold Alert Alting the Leiden University Library.

There are important findings in the study of this study after the transliteration process is done with regard to the practice of diplomacy in this study.Firstly, greetings of recognition used by Sultan Mahmud Riayat Syah to introduce him as a sender to the recipients. Secondly, words of praise to praising the recipient's personality. Thirdly, Satisfaction in making requests is used chiefly in expressing the purpose of sending, fourthly, the prayer approaches, which is to use statements that pray for the well-being of the recipient and the last are gift giving to strengthen relationships with each other. Thus, It can be stated that the method used by Sultan Mahmud Riayat Syah from Johor and Pahang adhered to the letter diplomatic features.

Therefore, the features a diplomatic Malay sultanate letter like this will hopefully contribute to further research and the establishment of guidelines and knowledge on diplomatic relations, especially the diplomatic institutions and ambassadors of the kingdom of the resources used during the reign of the kingdom of Malay sultanate period. In addition, it is proposed also to be expected that the assessment of the Malay sultanate letter from various fields will continue to grow and become an entity heritage to the next generation.

\section{Acknowledgement}

This paper is part of a research study of the lead author on the Development of Diplomatic Sultanate In the Malay Manuscript Collection at Leiden in the International Institute for Asian Studies (IIAS), Leiden University from September 2019 to May 2020. The lead author would like to express our deep appreciation to the University Putra Malaysia on financing this Sabbatical program.

\section{Corresponding Author}

Salmah Jan Noor Muhammad, Senior Lecturer, Universiti Putra Malaysia, Malaysia

Email:salmahjan@upm.edu.my,s.j.binti.noor.muhammad@umail.leidenuniv.nl 
INTERNATIONAL JOURNAL OF ACADEMIC RESEARCH IN BUSINESS AND SOCIAL SCIENCES

Vol. 10, No. 3, March, 2020, E-ISSN: 2222-6990 C 2020 HRMARS

\section{References}

Ab. Razak, A. K. (2005). Warkah-Warkah Kesultanan Melayu Lama Koleksi Perpustakaan Negara Malaysial: Analisis Komponen Dan Binaan Warkah. Jurnal Antarabangsa Dunia Melayu. Jilid 15, 183-201.

Ab. Razak, A. K., \& Reniwati. (2017). Illumination and Calligraphy in Malay Letters. Jurnal Arbitrer, 4 (2), 76-85.

Ahmed, M., @ Wang, Y. B. (2009). Diplomacy: Theory and Practice in Islam. Kuala Lumpur: Universiti Islam Antarabangsa.

Anselm, G. O. (1985). Seri Sumber Hidup 9 Doa dan Mengenal Diri. Jogjakarta: KANISIUS.

Asma, A. (2009). Ke arah glokal: dimensi budaya dalam pengurusan Malaysia. Kuala Lumpur: Institut Terjemahan Negara Malaysia Berhad.

Choudhury, G. W. (1993). The Prophet Muhammad His Life And Eternal Message. Kuala Lumpur: WHS Publications Sdn. Bhd.

Gallop, A. T. (1994). Warisan Warkah Melayu. London: The British Library.

Gallop, A. T. (2018). What's in a name? Malay seals as onomastic sources. Malay Literature, 31(1), 128.

George, Y. (1985). The Study of Language. London :Cambridge University Press.

Hashim, M. (2008). Hati Budi Melayu: Pengukuhan Menghadapi Cabaran Abad ke-21. Serdang: Penerbit Universiti Putra Malaysia.

Isnariah, I., Khushairi, F., Rashid, A. D. M.(2017). Hati Budi Melayu Dalam Warkah Melayu Lama. Jurnal Sultan Alauddin Sulaiman Shah, 4(2), 1-16.

Joseph, F. (1987). International Relation. London: Oxford University Press.

Koentjoro. (1989). Konsep Pengenalan Diri dalam AMT. Yogyakarta: Fakulti Psikologi UGM.

Amin, M. A. (2001). Tiada Kata Seindah Bahasa. Dalam Monograf Bahasa, Sastera, dan Budaya Melayu. Serdang, Fakulti Bahasa Moden dan Komunikasi.

Muhammad, H. H., \& Ab. Razak, A. K. (2019). Kohesi dalam Warkah Sosial Melayu Abad Ke-17 hingga Abad Ke-19. Jurnal Bahasa, 19 (1), 139-168.

Omardin, A. (2008). Sistem Politik dalam Islam. Kuala Lumpur: Yayasan Dakwah Islamiah Malaysia. Or. 2241 I (8) Surat Sultan Mahmud Riayat Syah kepada Gurnadur Jenderal Meneer Willem Arnold Alting. Leiden University Library.

Rohaini, A., \& Azlina, N. E. (2019). Nilai Estetika Dalam Warkah Raja-Raja Melayu: Suatu Kupasan. Persidangan Antarabangsa Sains Sosial Dan Kemanusiaan Kali Ke-4, Kolej Universiti Islam Antarabangsa Selangor, 24-25 April.

Saiful, B. K. (2015). Kajian Terhadap Persuratan Melayu Zaman Silam Perlu Diitingkatkan. Berita Kampus UKM. Retrieved from http://www.ukm.my/news/arkib/index.php/ms/beritakampus/2021-call-to-step-up-study-on-historical-malay-letters-.html.

Salmah, J. N. M. (2014). Bingkisan Hadiah Pencetus Keberlangsungan Hubungan Diplomatik Pada Zaman Kesultanan Melayu. IMAN, 2(2), 91-103.

Salmah, J. N. M. (2017). Kerencatan Hubungan Diplomatik Kesultanan Melayu Melaka, Johor dan Aceh. MANU, 25, 107-136.

Shaharuddin, A. A. (2006). Mengaplikasi Teori Psikologi Dalam Sukan. Kuala Lumpur: Utusan Publications and Distributors. 